\title{
An empirical analysis of the impact of China's financial development on current account
}

\author{
Wei $\operatorname{Li}^{1 a}$ Yuzan Dai ${ }^{1 * \mathrm{~b}}$ \\ ${ }^{1}$ College of Economics and Management Hefei University Hefei, China
}

\begin{abstract}
The global economy presents a situation of unbalanced development, and the imbalance of current account is the important aspect of global economic imbalance. This paper constructs the comparative advantage index of financial development and efficiency index of financial system that suits China's national conditions, demonstratively analyzes how the financial development affects current account.
\end{abstract}

\section{INTRODUCTION}

With the increase of economic and trade between countries, the development of the world economy also appears a more unbalanced phenomenon, especially the current account imbalance. In recent years, the huge differences in the development of financial markets have led more and more scholars to explore the root cause of current account imbalance from the perspective of financial market differences. From a macro point of view, the difference of financial development level will lead to the difference of conversion efficiency from savings to investment. From the micro perspective, the difference of financial development level leads to the change of international division of labor, which makes some countries focus more on the financial industry, while others focus more on the real economy manufacturing industry and so on. Studying the current account imbalance from the perspective of financial development difference can reveal the important role of financial development difference in the current account imbalance, and provide new ideas for the current account imbalance research, and further promote the development of related research.

\section{Literature review}

With the increasing globalization of international division of labor, international trade, and international finance, more and more scholars turn their research focus to the differences in financial development, in order to find new ways to solve the current account imbalance effectively.

\subsection{The transmission way of saving investment based on the macro level}

According to the research of Caballero et al. (2008), it can be found that the differences in the financial system supported by his research have an impact on the current account imbalance, which is believed to be due to the differences in the ability of one country to provide assets to the rest of the world. Mendoza (2010) found that in countries with high financial development levels, they would prefer to borrow from foreign countries to reduce their savings, and the integration of financial markets would lead to the long-term imbalance of the current global account. Pan Yaqiong (2016) conducted an empirical study based on the macroeconomic data of 59 countries from 1998 to 2013 and found that the differences in financial development level and financial openness have a significant impact on the whole sample. In Liu Fang's research (2020), the results show that financial development has a significant negative impact on the current account balance.

\subsection{Transmission way of the international division of labor based on the micro-level}

First, it studies the impact of financial development level on comparative advantage in the international division of labor. Kletzer, Bardhan (1987), and Baldwin (1989) first integrated financial, comparative advantage into the theory of international division of labor. Svarery and Vlahos (2005) studied OECD countries and found that the efficiency of the financial sector is the key factor affecting the international division of labor. Caballero and Krishna Murthy (2009) conducted a special study on the situation after the outbreak of the financial crisis in 2008. Lu Feng (2006) believes that China's long-term current account surplus is mainly due to its comparative advantage in the field of processing trade. Xu Jianwei and

\footnotetext{
a393965863@qq.com

*bCorrespondenceauthor.daiyuzan@126.com
} 
Yao Yang (2010) established a panel model for empirical analysis and found that the current account is significantly negatively related to the comparative advantage of financial development. According to the research of Yang Zhenzeng and Lu Jianming (2011), the difference of international division of labor position and situation will lead to the current account imbalance phenomenon, while the increase of financial development difference will expand the scale of current account imbalance.

\section{Empirical research}

\subsection{Model construction and variable description}

\section{1) VAR model}

In 1980, Simmons established the famous unstructured multi equation model. He took every variable in the system as a function of the lag value of all variables, thus established the multi variable autoregressive model, which is called VAR model. For this model, it does not need the economic theory foundation, it determines the dynamic structure of the model through the data itself. More importantly, the model can describe the dynamic process of random impact on variable system, so it is widely used in time series data analysis.

\section{2) variables}

Current account difference / GDP. The difference of current account can most intuitively reflect whether a country's current account situation is import greater than export or export greater than import, and whether foreign exchange reserves increase or decrease.

Financial efficiency. The financial efficiency index is used to examine how the financial development affects the current account through the way of saving and investment, as well as the degree and direction of influence. Therefore, in this paper, the index of financial efficiency mainly refers to the efficiency of the financial system to mobilize domestic savings. When the financial efficiency is higher, its saving mobilization ability is stronger. The lower the proportion of "leakage" in the process of transforming savings into investment in the financial system, the higher the conversion rate from savings to investment. Based on China's national conditions and the availability of data, in this study, "total loans / total deposits" is used to measure the efficiency of the financial system in transforming savings into investment.

The comparative advantage of financial industry over manufacturing industry. For the index of financial comparative advantage, it is used to examine how financial development affects the current items through the way of international division of labor, as well as the degree and direction of its influence. In this paper, the ratio of bank credit to GDP is used to reflect the level of China's financial development, so as to better reflect the main competition of China's financial market. Manufacturing value added / GDP is a common choice to measure the degree of manufacturing development, so the comparative advantage index of financial industry manufacturing industry is measured by the ratio of bank credit level / GDP to manufacturing value added / GDP.

The real effective exchange rate of RMB. Because the real effective exchange rate can comprehensively reflect the ratio of commodity prices between one country and many countries, it is widely used in the empirical study of the relationship between one country and its trading partners or trade competitors. When using the IMF to calculate the real effective exchange rate of $\mathrm{RMB}$, the indirect pricing method is adopted, taking 2000 as the base period.

Population dependency ratio. When the proportion of working age population increases, the saving rate of society will rise correspondingly. When the proportion of non-working age population increases, the saving rate decreases. If in a country, when young adults account for a large proportion of the population, there will be a peak investment, and when the long labor force accounts for a large proportion of the total population, there will be a high saving phenomenon. When children or the elderly account for a large proportion of the total population, there will be high savings and low consumption. When the savings are larger than the investment, the excess savings will inevitably flow out in the form of current account surplus, resulting in the imbalance of current account surplus.

\section{3) The range of data selection}

In this paper, the annual data from 1978 to 2018 are selected for empirical study. In this range, the data sample can basically reflect the growth process of China's economy. Current Account balance, GDP, population data, etc. all come from China Statistical Yearbook. For the actual effective exchange rate data, it is actually derived from the data published by the International Monetary Fund International Financial Statistics (IFS), while the total loans, total deposits, and bank credit data are derived from the "Almanac of China's Finance and Banking" over the years. CAB, DC, $\mathrm{BAZZ}, \mathrm{REER}$, and $\mathrm{LN}$ respectively represent the ratio of Current Account balance to GDP, the ratio of total loans to total deposits, the ratio of commercial bank credit to GDP and the ratio of manufacturing added value to GDP, the actual RMB Exchange rate and population dependency ratio.

\subsection{Empirical test}

\section{1) Unit root test}

According to the test results, the original sequences $\mathrm{CAB}, \mathrm{DC}, \mathrm{BAZZ}, \mathrm{REER}, \mathrm{LN}$ are all non-stationary sequences. But after the first order difference, $\triangle \mathrm{CAB}$, $\triangle \mathrm{DC}, \triangle \mathrm{BAZZ}, \triangle \mathrm{REER}, \triangle \mathrm{LN}$ are all stationary sequences, so they are all first-order single integer sequences. The results are shown in Table 1.

\section{2) Cointegration test}

Co-integration describes the long-term stable equilibrium relationship between variables, and due to the ratio of Current Account balance to GDP, total loan to total deposit, commercial bank credit to GDP ratio and manufacturing added value to GDP ratio The ratio, the actual effective exchange rate of RMB, and the population dependency ratio are all first-order 
single-integer sequences, so the long-term relationship between them can be tested for cointegration. For multivariate cointegration, Johansen method is usually used to test. For the sequence diagrams of CAB、DC、 BAZZ、REER and LN, there is an obvious upward trend. Therefore, when Johansen co integration test is carried out, the test form of observation sequence with linear deterministic trend and only intercept of co integration equation should be selected. The optimal lag order of VAR model is 2, and the lag order of cointegration test is 1 . In Table 2 , according to the cointegration test results, at the $5 \%$ confidence level, there is a cointegration relationship between the above variables, namely current There is a long-term stable equilibrium relationship between the ratio of account balance to GDP, the ratio of total loans to total deposits, the ratio of commercial bank credit to GDP and the ratio of manufacturing added value to GDP, the RMB real effective exchange rate, and the ratio of population support.

Table 1 ADF unit root test results

\begin{tabular}{|c|c|c|c|c|}
\hline variable & $\mathrm{ADF}$ test value & $\begin{array}{l}\text { Test type } \\
(\mathrm{c}, \mathrm{t}, \mathrm{k})\end{array}$ & Critical value & Conclusion \\
\hline $\mathrm{CAB}$ & -1.984728 & $(\mathrm{c}, \mathrm{t}, 0)$ & $-3.233456^{* *}$ & Unstable \\
\hline$\triangle \mathrm{CAB}$ & -4.241934 & $(\mathrm{c}, \quad 0,0)$ & -3.724070 & Stable \\
\hline BAZZ & -0.983409 & $(c, 0,0)$ & $-2.627420 * *$ & Unstable \\
\hline$\triangle \mathrm{BAZZ}$ & -4.847462 & $(0,0,0)$ & -3.711457 & Stable \\
\hline $\mathrm{DC}$ & -2.700857 & $(\mathrm{c}, \mathrm{t}, 0)$ & $-3.587527 * *$ & Unstable \\
\hline$\triangle \mathrm{DC}$ & -4.990932 & $(\mathrm{c}, \quad 0,0)$ & -3.711457 & Stable \\
\hline REER & -3.070683 & $(\mathrm{c}, \mathrm{t}, 0)$ & $-3.261452 * *$ & Unstable \\
\hline$\triangle \mathrm{REER}$ & -3.880395 & $(\mathrm{c}, \mathrm{t}, 1)$ & -2.664853 & Stable \\
\hline $\mathrm{LN}$ & 3.224973 & $(c, 0,0)$ & $-2.638752 * *$ & Unstable \\
\hline$\triangle \mathrm{LN}$ & -6.936067 & $(\mathrm{c}, \mathrm{t}, 0)$ & -4.356068 & Stable \\
\hline
\end{tabular}

Note: (1)In the test type, $\mathrm{c}$ and $\mathrm{t}$ represent the constant term and the trend term, and $\mathrm{k}$ represents the lag order used;(2) $\triangle$ is the first-order difference of the sequence; $(3) *$ It represents the critical value at the $5 \%$ significance level, ** represents the critical value at the $10 \%$ significance level, and the rest is the critical value at the $1 \%$ significance level.

Table 2 Johansen cointegration test results

\begin{tabular}{c|c|c|c|c}
\hline Original hypothesis & Trace statistics & $5 \%$ threshold & Maximum eigenvalue & $5 \%$ threshold \\
\hline None & 126.5004 & 69.81889 & 62.48980 & 33.87687 \\
\hline $\begin{array}{c}\text { au of Economic } \\
\text { Research, 2012. }\end{array}$ & 64.01056 & 47.85613 & 32.29700 & 27.58434 \\
\hline At most 2 & 31.71356 & 29.79707 & 23.95696 & 21.13162 \\
\hline At most 3 & 7.756597 & 15.49471 & 6.886023 & 14.26460 \\
\hline At most 4 & 0.870574 & 3.841466 & 0.870574 & 3.841466 \\
\hline
\end{tabular}

Note: $* *$ Represents the critical value at the $10 \%$ significance level, * represents the rejection of the original hypothesis at the $5 \%$ significance level. The rest are critical values at the $1 \%$ significance level, with lag intervals of 1 to 2 .

Long term equilibrium analysis

The following error correction models are established:

$$
\Delta y_{t}=\Phi_{0}+\Phi Z_{t-1}+\sum_{i=1}^{y} \Psi_{i} \Delta y_{t-i}+\varepsilon t
$$

Among them, $\Delta$ is the first-order difference operator, $y_{t}=\left(L n Y_{t}, L n E_{t}, L n K_{t}, L n T_{t}, L n M t\right)^{t}$

$\Phi_{0}$ is the unconstrained dependent variable, $\Phi_{\text {is }}$ the error correction vector, which indicates the adjustment speed when the variable deviates from the long-term equilibrium state. $Z t-1=A y t-1$ indicates that there is a long-term stable relationship between vectors, i.e. cointegration relationship; $\Psi_{i}$ is a short-term parameter, indicating the short-term influence among variables, $\mathrm{P}$ is the lag order; $\varepsilon^{t}$ is the random error term.

\section{$C A B=-52.856220 C-56.47480 B A Z Z+67.47043 L N-2.434588 R E E R$}

According to the cointegration equation, it can be seen that it has a negative impact on the current account in China in the long term, that is to say, improving the efficiency of China's financial system, improving the comparative advantage of financial industry and manufacturing industry, and the appreciation of RMB's real effective exchange rate will result in the decrease of China's current account surplus, while the increase of population dependency ratio will have a positive impact on the current account. In terms of its influence, the loan deposit ratio, the comparative advantage ratio of financial industry and manufacturing industry, and the real effective exchange rate of RMB have an important impact on the balance of current account.

Table 3 optimal lag order of VAR model

\begin{tabular}{lllllll}
\hline Lag & LogL & LR & FPE & AIC & SC & HQ \\
\hline
\end{tabular}




\begin{tabular}{ccccccc}
\hline 0 & 55.27691 & NA & $8.69 \mathrm{e}-09$ & -4.371906 & -4.125059 & -4.309824 \\
1 & 157.1879 & 150.6511 & $1.15 \mathrm{e}-11$ & -11.05982 & -9.578741 & -10.68733 \\
2 & 202.0019 & $46.76240^{*}$ & $2.96 \mathrm{e}-12^{*}$ & $-12.78277^{*}$ & $-10.06746^{*}$ & $-12.09988^{*}$ \\
\hline
\end{tabular}

Note: * indicates that it is selected by such criteria.

3) Dynamic impact analysis

According to the above results, it can be seen that CAB, DC, BAZZ, REER and LN are the first-order single integer data. Through the test, the optimal autoregressive order is 2 . See Table 3 for specific results. influence process of loan to deposit ratio, financial industry to GDP ratio and manufacturing industry added value to GDP ratio, RMB real effective exchange rate, population dependency ratio and current account to GDP ratio. The results are shown in Figure 1 and table 4.

By using impulse response function and variance decomposition, the paper further analyzes the dynamic

Response to C holesky One S.D. I nnovations \pm 2 S.E

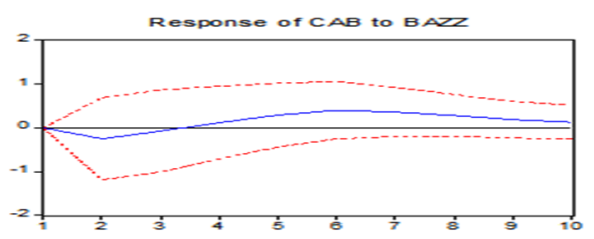

Response of $C A B$ to $D C$
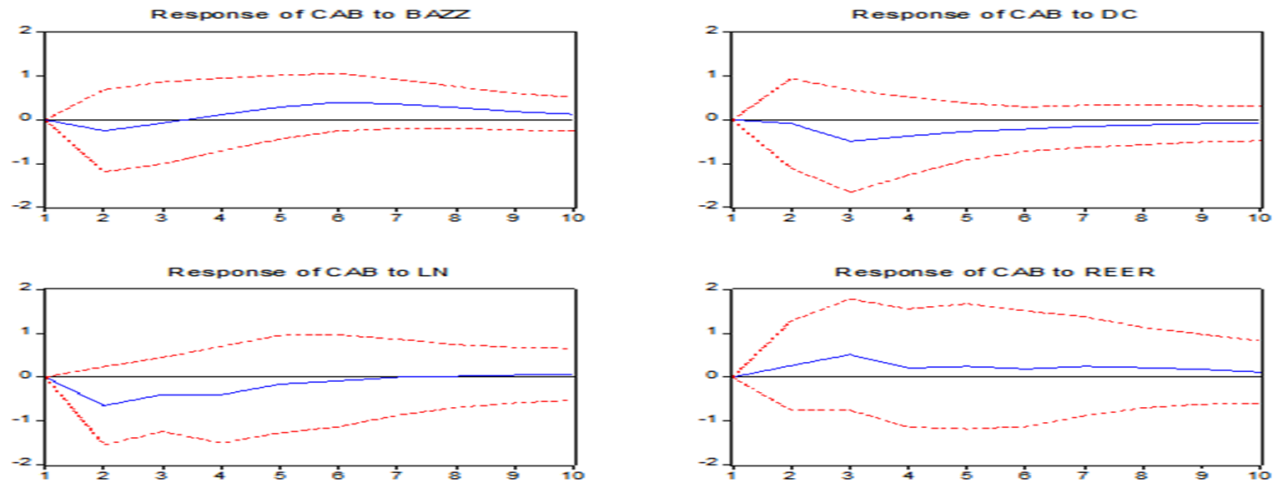

Figure 1 response function of cab caused by structural impact of BAZZ, DC, REER and LN

Table 4 Y variance decomposition results

\begin{tabular}{c|c|c|c|c|c|c}
\hline period & S.E. & CAB & BAZZ & DC & LN & REER \\
\hline 1 & 2.122588 & 100.0000 & 0.000000 & 0.000000 & 0.000000 & 0.000000 \\
2 & 2.797558 & 92.80768 & 0.800003 & 0.087587 & 5.421881 & 0.882849 \\
3 & 3.064801 & 86.91913 & 0.721662 & 2.601878 & 6.194504 & 3.562827 \\
4 & 3.134683 & 83.88732 & 0.838980 & 3.869996 & 7.563742 & 3.839958 \\
5 & 3.184971 & 82.01318 & 1.647993 & 4.449558 & 7.569930 & 4.319339 \\
6 & 3.259708 & 80.48613 & 3.095938 & 4.666278 & 7.295443 & 4.456212 \\
7 & 3.325020 & 79.32654 & 4.146432 & 4.683523 & 7.011679 & 4.831823 \\
8 & 3.362474 & 78.54795 & 4.753498 & 4.702502 & 6.860080 & 5.135967 \\
9 & 3.379929 & 78.08670 & 5.015349 & 4.724383 & 6.808371 & 5.365194 \\
10 & 3.387178 & 77.84378 & 5.136304 & 4.754514 & 6.811318 & 5.454084 \\
\hline
\end{tabular}

\section{Concluson}

Financial efficiency has a very significant impact on China's current account surplus, and its impact is negative, which can improve financial efficiency and reduce the amount of current account surplus. In the financial industry and manufacturing industry, the change in the ratio of the difference between the comparative advantage indicators BAZZ and Current Account in GDP is also reversed, and the magnitude of the reverse change is also relatively large. The larger the indicator, the greater the financial industry's advantage over the manufacturing industry, and the lower the current account surplus. China's financial industry should keep pace with the development of the times and create a good financial environment for the development of the manufacturing industry.

\section{Acknowledgement}

This research is supported by the Research Foundation for Talents of Hefei University (No. 18-19RC64), and also supported by Humanities and Social Science Project of Anhui Provincial Education Department (No. SK2018ZD047).

\section{References}


[1] Alfaro, Chanda Kalemli-Ozcan and Sayek. FDI and economic growth: the role of local financial markets[J]. Journal of International Economics Elsevier, 2004, 64(1).

[2] Chinn,M.D.,Ito,H..What matters for financial development? Capital controls, institutions, and interactions[J]. Journal of Development Economics, 2006, 81(1).

[3] Demirgu, Kunt A, Maksimovic V. Law, finance, and firm growth[J]. The Journal of Finance, 1998, 53(6).

[4] Hennksen,E. R. A Demographic Explanation of US and Japanese Current Account Behavior, Unpublished manuscript, Camegie Mellon University. 2002.

[5] Helena S., Jonas M.. Markets for risk and openness to trade: how are they related?[J]. Journal of International Economics, 2002, 57 (2).

[6] Sebnem,K.O., Efias P., JoseL. P.. What lies beneath the euro's effect on financial integration? Currency risk, legal harmonization, or trade? [J]. Journal of International Economics, 2010,81(1).

[7] Svalery,H., Vlachos, J., Financial markets, the pattern of industrial specialization and comparative advantage: Evidence from OECD countries, European Economic Review, 2005, 49(1).

[8] Obstfeld,M.. Does the current account still matter?[R]. National Bure 